\title{
ANTIHYPERTENSIVE ACTIVITY ETHANOLIC EXTRACT OF BULB ELEUTHERINE AMERICANA MERR ON FRUCTOSE-INDUCED HYPERTENSION RATS
}

\author{
PATONAH HASIMUN ${ }^{1}$, HASBALLAH ZAKARIA ${ }^{2}$, ELIS SUSILAWATI' ${ }^{1}$, JEANY DWIYULIA WARDIONO ${ }^{1}$
}

1Department of Pharmacology Research Group, Bandung School of Pharmacy, Street of Soekarno-Hatta no. 754, Bandung, West Java, Indonesia, ${ }^{2}$ Department of Biomedical Engineering, Institute of Technology Bandung, Indonesia Email: patonah.stfb@gmail.com

Received: 26 Sep 2016 Revised and Accepted: 19 Jun 2017

\begin{abstract}
Objective: This study aimed to evaluate ethanolic extract of bulb of Eleutherine americana Merr as antihypertensive.

Methods: This study examined the effect of ethanol extract of bulb of Eleutherine americana Merr on urine volume, blood pressure, and electrocardiogram (ECG) profile. Diuretic activity was evaluated by the Lipschitz method. Furosemide (3.6 mg/kg) used as standard drug. Animal rats model of hypertension were induced by fructose $66 \%$ in the diet for $21 \mathrm{~d}$. Captopril $(2.5 \mathrm{mg} / \mathrm{kg})$ used as standard antihypertension. Parameters measured were urine volume for $24 \mathrm{~h}$, systolic and diastolic blood pressure, and electrocardiogram profile.

Results: High fructose diet for 21 d reduced R-R, P-R interval of the electrocardiogram, increased systolic and diastolic blood pressure and heart rate compared to normal group statistically significant $(\mathrm{p}<0.05)$. Animals received an ethanolic extract of the bulb of Eleutherine americana Merr doses of 25, 50, $100 \mathrm{mg} / \mathrm{kg}$ showed lowered systolic and lowered diastolic blood pressure (except for a dose of $100 \mathrm{mg} / \mathrm{kg}$ ). Dose of $25,50 \mathrm{mg} / \mathrm{kg}$ lowered systolic blood pressure was comparable to captopril $2.5 \mathrm{mg} / \mathrm{kg}$ ( $\mathrm{p}>0.05)$. The group received a dose of $100 \mathrm{mg} / \mathrm{kg}$ showed diuretic activity comparable to furosemide $3.6 \mathrm{mg} / \mathrm{kg}(\mathrm{p}>0.05)$. The group received a dose of $25,50,100 \mathrm{mg} / \mathrm{kg}$, showed improved on R-R, P-R interval of the electrocardiogram, and heart rate.
\end{abstract}

Conclusion: It can be concluded that ethanolic extract of bulb Eleutherine americana Merr play important role in regulating blood pressure, increased urine volume and improved electrocardiogram profile.

Keywords: Eleutherine americana Merr, Blood pressure, Diuretic, Fructose, Electrocardiogram profile

(c) 2017 The Authors. Published by Innovare Academic Sciences Pvt Ltd. This is an open access article under the CC BY license (http://creativecommons.org/licenses/by/4.0/) DOI: http://dx.doi.org/10.22159/ijpps.2017v9i8.15383

\section{INTRODUCTION}

Hypertension is an elevation of systolic blood pressure (SBP) to 140 $\mathrm{mm} \mathrm{Hg}$ or more, and/or an elevation of diastolic blood pressure (DBP) to $90 \mathrm{~mm} \mathrm{Hg}$ or more. Hypertension classified into different types of hypertension, such as systolic-diastolic hypertension, isolated systolic hypertension or isolated diastolic hypertension [1]. Isolated systolic hypertension (ISH) is an increase in systolic blood pressure (SBP) without an increase in diastolic blood pressure (DBP). It is more common in older adults than systolic-diastolic hypertension $(\mathrm{SDH})$, but both contribute similarly to cardiovascular events [2].

Blood pressure determined by cardiac output and vascular resistance. An increase in cardiac output and/or vascular resistance may result in hypertension. Chronic hypertension can cause changes in the physiology of the heart. This can be measured using electrocardiogram.

Hypertension is a common disease and a major risk factor for stroke, myocardial infarction, vascular disease, and chronic kidney disease [3]. Modern lifestyle might be one of the prime causes of hypertension. High fructose diet in our lifestyle may induce hypertension [4]. Animal and human study has shown that a high fructose diet increased blood pressure [5-7]. As we are aware that hypertension is a silent killer if left untreated may result in a cardiovascular and cerebrovascular complication. In the general population, a tight control of blood pressure can prevent the cardiovascular complications of hypertension. Antihypertension agents are one of the choices for control of high blood pressure. The drugs used in hypertension have a variety of mechanisms of action including diuresis, vasodilation, and antagonism of the reninangiotensin-aldosterone system. Antihypertension agents should be carefully provided to prevent the evidence of adverse events, because adverse events may induce non-adherence to medication.
Herbal medicine empirically used by Indonesian people to cure many diseases including high blood pressure. One of promising herbal medicine as antihypertension is the bulb of Eleutherine americana Merr. The bulb of Eleutherine americana Merr which belongs to the family Iridaceae, a plant originated from West Kalimantan, is known as a Dayak onion. This plant has been used by the Dayak community for generations as a remedy for some types of diseases including breast cancer, gastrointestinal cancer, diabetes, cholesterol, and high blood pressure [8].

Dayak onion contained naphthoquinone compounds and its derivatives such as elecanacine, eleutherine, eleutherol, eleuthernone. Naphthoquinones compounds are known as antimicrobial, antifungal, and antiparasitic. Moreover, naphthoquinones showed antioxidant activity, that protecting the body against free radicals that trigger many diseases, including cardiovascular diseases [7, 8].

This study aimed to determine the role of the ethanolic extract of bulb Eleutherine americana Merr in regulating blood pressure as well as its influence on the electrocardiogram profile in fructoseinduced hypertensive rats.

\section{MATERIALS AND METHODS}

\section{Plants materials}

This study was conducted in the Pharmacology Laboratory, Bandung School of Pharmacy, Indonesia. Bulb of Eleutherine americana Merr (EA) was collected from Manoko, Lembang, Bandung, West Java, Indonesia and botanically identified at Biology Faculty, Padjadjaran University, Indonesia. The bulb were cut into small pieces, dried, and extracted with ethanol 96\% (analytical grade, purchased from Brataco, Indonesia) for $3 \mathrm{~d}$. The extracts were filtered and concentrated by rotary evaporator. Phytochemical analysis was carried out on the dry extract. Doses of Eleutherine americana Merr bulb extracts were $25,50,100 \mathrm{mg} / \mathrm{kg}$. 


\section{Animals}

Male Wistar rats of 2 mo age and weighed about 200-250 gram were used in this study. Before treatment, animals were adapted to a cage room temperature $\left(25^{\circ} \mathrm{C}\right)$ and were given access to food and drink for a week. This study was conducted in the Laboratory of Pharmacology, Bandung School of Pharmacy, Bandung, West Java, Indonesia. All experiment procedure was approved by the local animal ethics committee (no. 315/UN6. C1.3.2/KEPK/PN/2016).

\section{Diuretic study}

Eighteen male Wistar rats were divided randomly into 6 groups of 3 animals in each group. Group 1 and 2 received vehicle of the drug, group 3 received Furosemide (generic drug purchased from a local pharmacy) dose of $3.6 \mathrm{mg} / \mathrm{kg}$, group 4-6 received an ethanolic extract of bulb Eleutherine americana Merr doses of 25, $50,100 \mathrm{mg} / \mathrm{kg}$ respectively. Thirty minutes after a given test drug, a group of 2-6 received $5 \mathrm{ml}$ drinking waters orally. Rats were placed in metabolic cages to separate urine and faeces. The volume of urine collected was measured at the end of $24 \mathrm{~h}$. During this period, no food was made available for all animals. Diuretic activity determined by urine volume compares to control group.

\section{Animal model hypertension}

Eighteen male Wistar rats were divided randomly into 6 groups of 3 animals in each group. Hypertension was induced by fructose $66 \%$ in the diet for $21 \mathrm{~d}$. Test drug was given for $21 \mathrm{~d}$ along with a high fructose diet. Group 1 and 2 received vehicle of the drug, group 3 received captopril (generic drug purchased from a local pharmacy) dose of $2.5 \mathrm{mg} / \mathrm{kg}$, group $4-6$ received Eleutherine americana Merr extract doses of 25, 50, $100 \mathrm{mg} / \mathrm{kg}$ respectively. Group 1 received standard diet while group 2-6 received 66\% fructose (purchased from Brataco, Indonesia) diet for $21 \mathrm{~d}$. Systolic and diastolic blood pressure were measured at 0 and $21 \mathrm{~d}$ by noninvasive blood pressure instrument for rodents (CODA® Kent Scientific, USA).

Table 1: Number group of treatment for antihypertension and ECG study

\begin{tabular}{lll}
\hline No & Diet & Drug \\
\hline 1 & Normal & $0.5 \%$ CMC (carboxy methyl cellulose) $5 \mathrm{ml} / \mathrm{kg}$ \\
2 & High fructose diet (66\% fructose) & $0.5 \%$ CMC (carboxy methyl cellulose) $5 \mathrm{ml} / \mathrm{kg}$ \\
3 & High fructose diet (66\% fructose) & Captopril $2.5 \mathrm{mg} / \mathrm{kg}$ \\
4 & High fructose diet (66\% fructose) & Ethanolic extract of bulb Eleutherine americana Merr $(25 \mathrm{mg} / \mathrm{kg})$ \\
5 & High fructose diet (66\% fructose) & Ethanolic extract of bulb Eleutherine americana $\mathrm{Merr}(50 \mathrm{mg} / \mathrm{kg})$ \\
6 & High fructose diet (66\% fructose) & Ethanolic extract of bulb Eleutherine americana Merr $(100 \mathrm{mg} / \mathrm{kg})$ \\
\hline
\end{tabular}

\section{Electrocardiogram measurement}

In this research, electrocardiogram (ECG) measured the change in ECG profile after high fructose diet for $21 \mathrm{~d}$. An animal ECG device (developed by the Department of Biomedical, Institute of Technology Bandung, ITB) connected directly to a laptop. Three electrodes were put on the right foot and two hands of the rat. The rats were either restrained to a platform or hold by hand. The ECG device was developed based on a single-lead ECG analog front end AD8232 chip. The chip was configured with a $0.5 \mathrm{~Hz}$ two-pole high-pass filters and followed by a two-pole $40 \mathrm{~Hz}$ low-pass filter. The op amp stage was set for a total system gain of 1100 . The ECG analog signal was then converted into digital by using 14 bits resolution ADC (Advantech USB 4704) with a sampling rate of 1000 samples/second. The ECG signal was recorded on the PC for 10 seconds.

\section{Data analysis}

Data were collected for statistical analysis. The value is expressed as mean \pm standard deviation mean from three rats for each group. The results were statistically analysis by one-way ANOVA. The significant difference was confirmed by $\mathrm{p}$-value $<0.05$.

\section{RESULTS}

\section{Percentage of yield extract}

Percentage of yield extract of bulb Eleutherine americana Merr was found to be $5.7 \% \mathrm{w} / \mathrm{w}$.

\section{Phytochemical screening}

The result of phytochemical analysis of an ethanolic extract of bulb Eleutherine americana Merr revealed the presence of flavonoids, saponin, and phenolic compounds.

\section{Effect on urine volume}

Group 3-6 showed increased in urine output statistically significant compared to normal and positive groups $(p<0.05)$. The diuretic effect of group 4 and 5 showed significant different compared to group 3, while a group 6 showed comparable to group 3.

Table 2: Effect of furosemide and ethanolic extract of bulb Eleutherine americana Merr on urine volume for $24 \mathrm{~h}$ of rats

\begin{tabular}{ll}
\hline Group of treatment & Urine volume \pm SD (ml) \\
\hline Normal control & $0.4 \pm 0.1$ \\
Water & $2.8 \pm 0.2$ \\
Water+furosemide $(3.6 \mathrm{mg} / \mathrm{kg})$ & $5.3 \pm 0.2^{*}$ \\
Water+bulb Eleutherine americana Merr $(25 \mathrm{mg} / \mathrm{kg})$ & $4.2 \pm 0.2^{*}$ \\
Water+bulb Eleutherine americana Merr $(50 \mathrm{mg} / \mathrm{kg})$ & $3.5 \pm 0.1^{*}$ \\
Water+bulb Eleutherine americana Merr $(100 \mathrm{mg} / \mathrm{kg})$ & $5.2 \pm 0.2^{*}$ \\
\hline
\end{tabular}

Values are expressed as mean \pm SD from three rats. Significant at $* \mathrm{p}<0.05$, when compared to high fructose group

\section{Systolic and diastolic blood pressure}

Fructose diet for $21 \mathrm{~d}$ in the animal study showed increased in systolic and diastolic blood pressure (group 2). Administration of bulb Eleutherine americana Merr extract for $21 \mathrm{~d}$ revealed a reduction in systolic, diastolic blood pressure and heart rate (group 4-6) that statistically significant compared to group 2 . Group 4 and 5 that received extract dose of $25,50 \mathrm{mg} / \mathrm{kg}$ showed a comparable effect in systolic blood pressure reduction but significantly different in diastolic blood pressure compared to group 3 (received captopril $2.5 \mathrm{mg} / \mathrm{kg}$ ) (table 3). 
Table 3: Effect of captopril and ethanolic extract of bulb Eleutherine americana Merr on systolic blood pressure of rats

\begin{tabular}{ll}
\hline Group of treatment & Systolic blood pressure \pm SD (mmHg) \\
\hline Normal control & $111.67 \pm 0.6$ \\
High fructose & $148.67 \pm 1.53$ \\
High fructose+captopril $(2.5 \mathrm{mg} / \mathrm{kg})$ & $101.33 \pm 2.52^{*}$ \\
High fructose+bulb Eleutherine americana Merr $(25 \mathrm{mg} / \mathrm{kg})$ & $104.33 \pm 2.52^{*}$ \\
High fructose+bulb Eleutherine americana Merr $(50 \mathrm{mg} / \mathrm{kg})$ & $104.67 \pm 2.52^{*}$ \\
High fructose+bulb Eleutherine americana Merr $(100 \mathrm{mg} / \mathrm{kg})$ & $129.67 \pm 2.08^{*}$ \\
\hline
\end{tabular}

Values are expressed as mean \pm SD from three rats. Significant at $* \mathrm{p}<0.05$, when compared to high fructose group

Table 4: Effect of captopril and ethanolic extract of bulb Eleutherine americana Merr on diastolic blood pressure of rats

\begin{tabular}{lc}
\hline Group of treatment & Diastolic blood pressure \pm SD (mm Hg) \\
\hline Normal control & $80.33 \pm 1.53$ \\
High fructose & $102.67 \pm 2.52$ \\
High fructose+captopril $(2.5 \mathrm{mg} / \mathrm{kg})$ & $78.00 \pm 2.00^{*}$ \\
High fructose+bulb Eleutherine americana Merr $(25 \mathrm{mg} / \mathrm{kg})$ & $85.67 \pm 2.08^{*}$ \\
High fructose+bulb Eleutherine americana Merr $(50 \mathrm{mg} / \mathrm{kg})$ & $86.67 \pm 2.52^{*}$ \\
High fructose+bulb Eleutherine americana Merr $(100 \mathrm{mg} / \mathrm{kg})$ & $113.33 \pm 2.52 *$ \\
\hline
\end{tabular}

Values are expressed as mean \pm SD from three rats. Significant at ${ }^{*} \mathrm{p}<0.05$, when compared to high fructose group High fructose diet for $21 \mathrm{~d}$ showed a reduction in R-R, P-R waves and increased in heart rate. Administration of captopril and bulb Eleutherine americana Merr improved of ECG profile and heart rate (table 5 and fig. 1).

Tabel 5: Effect of captopril and ethanolic extract of bulb Eleutherine americana Merr on electrocardiogram (ECG) profile of rats

\begin{tabular}{|c|c|c|c|c|}
\hline \multirow[t]{2}{*}{ Group of treatment } & \multicolumn{4}{|c|}{ Mean of interval wave \pm SD (minutes) } \\
\hline & R-R & P-R & QRS & S-T \\
\hline Normal control & $0.11 \pm 0.006^{*}$ & $0.03 \pm 0.006^{*}$ & $0.03 \pm 0.008$ & $0.03 \pm 0.01$ \\
\hline High fructose & $0.10 \pm 0.002$ & $0.02 \pm 0.003$ & $0.04 \pm 0.008$ & $0.03 \pm 0.004$ \\
\hline High fructose+captopril $(2.5 \mathrm{mg} / \mathrm{kg})$ & $0.12 \pm 0.006^{*}$ & $0.03 \pm 0.006^{*}$ & $0.03 \pm 0.003$ & $0.03 \pm 0.006$ \\
\hline High fructose+bulb Eleutherine americana $\operatorname{Merr}(25 \mathrm{mg} / \mathrm{kg})$ & $0.12 \pm 0.004^{*}$ & $0.03 \pm 0.004^{*}$ & $0.03 \pm 0.004$ & $0.03 \pm 0.009$ \\
\hline High fructose+bulb Eleutherine americana Merr ( $50 \mathrm{mg} / \mathrm{kg})$ & $0.11 \pm 0.005^{*}$ & $0.03 \pm 0.002^{*}$ & $0.03 \pm 0.006$ & $0.04 \pm 0.01$ \\
\hline High fructose+bulb Eleutherine americana Merr (100 mg/kg) & $0.12 \pm 0.004^{*}$ & $0.03 \pm 0.004^{*}$ & $0.04 \pm 0.003$ & $0.03 \pm 0.006$ \\
\hline
\end{tabular}

Values are expressed as mean \pm SD from three rats. Significant at $* \mathrm{p}<0.05$, when compared to high fructose group

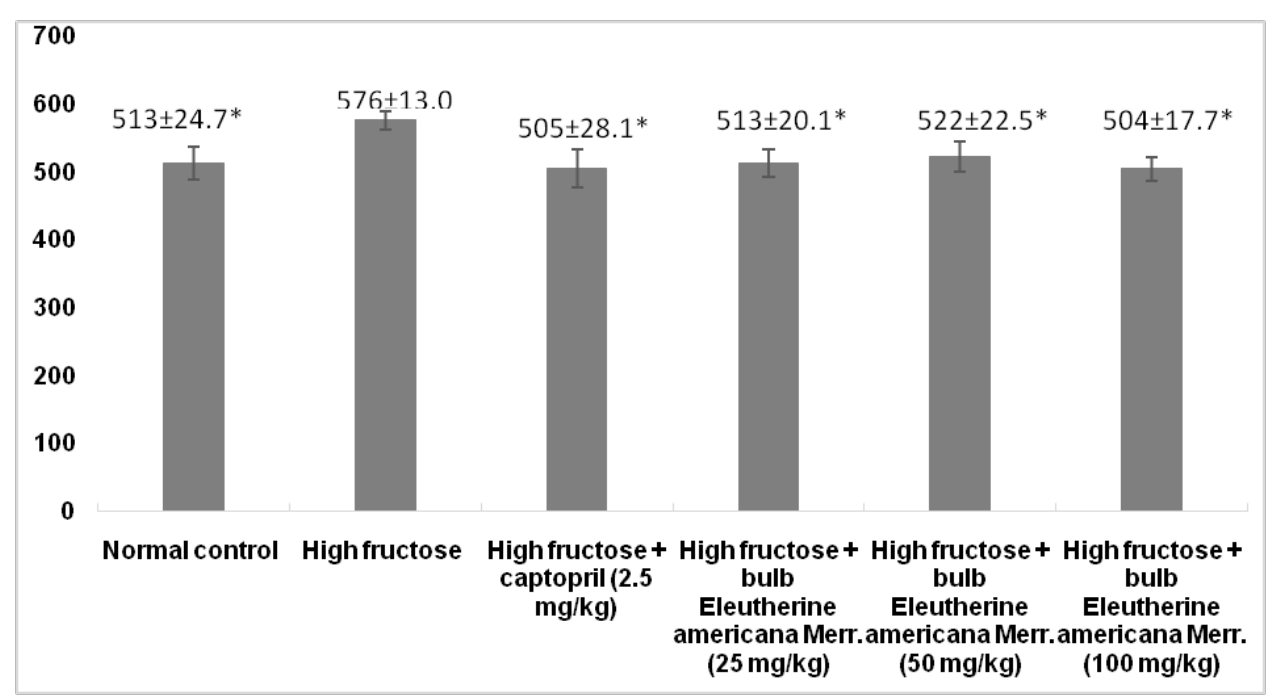

Fig. 1: Effect of captopril and ethanolic extract of bulb Eleutherine americana Merr on the heart rate of rats. Values are expressed as mean \pm SD from three rats. Significant at ${ }^{*} \mathbf{p}<0.05$, when compared to high fructose group

\section{DISCUSSION}

High-fructose diets increase the activity of sodium and chloride transporters, resulting in a state of salt overload in an animal study. This condition increases blood pressure. Moreover, Excess fructose can activate vasoconstrictors, inactivate vasodilators, and overstimulate the sympathetic nervous system, these can contribute to hypertension [10]. In accordance with our study that fructose diet for $21 \mathrm{~d}$ showed elevated in systolic and diastolic blood pressure and increased heart rates (table 3 and 4). Fructose diet showed changed in electrocardiogram profile (table 5).

Extract of bulb Eleutherine americana Merr dose of 25, 50 and 100 $\mathrm{mg} / \mathrm{kg}$ showed diuretic activity. The dose of $100 \mathrm{mg} / \mathrm{kg}$ was the 
highest diuretic effect comparable to furosemide $3.6 \mathrm{mg} / \mathrm{kg}$. Diuretic furosemide increased the urinary output as well as an increase of sodium, potassium and chloride ions concentration in urine. This effect is valuable in the treatment of hypertension and enhancing the effect of others antihypertensive agents [11]. Moreover, increase in urine output result in systolic and diastolic blood pressure reduction, and heart rates reduction. Our study showed that provision of bulb Eleutherine americana Merr extract dose of 25,50, and $100 \mathrm{mg} / \mathrm{kg}$ for $21 \mathrm{~d}$ reduced systolic and diastolic blood pressure, and heart rates compared to control group (table 3 and 4, fig. 1).

The electrocardiogram (ECG) is an important tool for the study of cardiac electrophysiology [12]. The fluid loss during diuretic therapy results in a change of ECG including an increase in the amplitudes of P-waves, QRS complexes, and T waves; durations of P waves, QRS complexes, and QT intervals [13]. The hazard of diuretic-induced ventricular ectopic activity warrants correction of hypokalemia. Furosemide increased the risk of hypokalemia [14] results in increased heart rate.

In the present study showed that high fructose diet decreased of RR and PR intervals, and increased the heart rates. Administration extract of bulb Eleutherine americana Merr for $21 \mathrm{~d}$ improved ECG profile, RR, and PR intervals, and heart rates comparable to normal group ( $p>0.05$ ) (table 5, fig. 1 ).

Heart rate variability has been used as an important tool for the study of cardiac autonomic control [15]. Variability in heart rate can increased risk for ventricular arrhythmia event [16]. Our study suggested the role of bulb Eleutherine americana Merr in preventing ventricular arrhythmia by controlling the heart rates.

The Multiple Risk Factor Intervention Trial found that for any level of diastolic and systolic blood pressure was the major determinant of cardiovascular risk in aged over $50 \mathrm{y}$. The elevation of systolic blood pressure raises left ventricular afterload and myocardial work. Left ventricular hypertrophy is a known risk factor for congestive heart failure and cardiovascular events that associated with arterial stiffness (correlated with atherosclerosis) [17]. The present study showed that administration of bulb Eleutherine americana Merr reduced systolic and diastolic blood pressure. It suggested that bulb Eleutherine americana Merr has an important role in ameliorating the arterial stiffness. Further study needed.

\section{CONCLUSION}

The bulb of Eleutherine americana Merr showed antihypertensive activity in fructose-induced hypertension animal model. It has a potential role in regulating systolic, diastolic blood pressure and heart rate. Proposed mechanism of bulb Eleutherine americana Merr in lowering blood pressure are stimulating urine output (diuretic) and improvement of heart rate.

\section{AUTHOR CONTRIBUTION}

Patonah Hasimun directed the entire series of research and evaluates the overall research results.

Hasballah Zakaria developed a test method and validated the results of electrocardiogram measurements.

Elis Susilawati evaluated the results of the diuretic test and animal handling treatment.

Jeany Dwiyulia Wardiono is a technical executive in antihypertensive research.

\section{CONFLICT OF INTERESTS}

Declared none

\section{REFERENCES}

1. LL Tin, DG Beevers, GY H Lip. Systolic vs diastolic blood pressure and the burden of hypertension. J Hum Hypertens 2002;16:147-50.
2. Raya E Kheirbek, Ross Fletcher, Prakash Deedwania, Nawar Shara, Gregg C Fonarow, Maciej Banach, et al. Abstract 18649: comparative impact of isolated systolic hypertension vs systolic-diastolic hypertension on incident heart failure and allcause mortality in community-dwelling older adults. Circulation 2014;130:A18649.

3. Chobanian AV, Bakris GL, Black HR, Cushman WC, Green LA, Izzo JL, et al. The seventh report of the joint national committee on prevention, detection, evaluation, and treatment of high blood pressure. J Natl Cancer 2003;289:2560-72.

4. Alice Victoria Klein, Hosen Kiat. The mechanisms underlying fructose-induced hypertension: a review. J Hypertens 2015; 33:912-20.

5. Richard J Johnson, Mark S Segal, Yuri Sautin, Takahiko Nakagawa, Daniel I Feig, Duk-Hee Kang, et al. Potential role of sugar (fructose) in the epidemic of hypertension, obesity and the metabolic syndrome, diabetes, kidney disease, and cardiovascular disease. Am J Clin Nutr 2007;86;899-906.

6. Brown Clive M, Dulloo Abdul G, Yepuri G, Montani JP. Fructose ingestion acutely elevates blood pressure in healthy young humans. Am J Physiol: Regul Integr Comp Physiol 2008;294: R730-7.

7. Fitri Y, Rosidah, Suwarso E. Effects of inhibition cell cycle and apoptosis of sabrang onion extract (Eleutherine bulbosa (Mill.) $U r b$.) on breast cancer cells. Pharmacy Faculty of Universitas Sumatera Selatan. Skripsi; 2014.

8. Daryono BS, Rahmadani WD, Sudarsono. Identification of bawang sabrang (Eleutherine americana Merr Ex K. Heyne) in Indonesia based on chromosome characters. Indonesian J Pharms 2012;24:22-9.

9. Tran LT, Yuen VG, McNeill JH. The fructose-fed rat: a review on the mechanisms of fructose-induced insulin resistance and hypertension. Mol Cell Biochem 2009;332:145-59.

10. Pedro P Pereira-Junior, Moacir Marocolo, Fabrício P Rodrigues, Emiliano Medei, José HM Nascimento. Noninvasive method for electrocardiogram recording in conscious rats: feasibility for heart rate variability analysis. An Acad Bras Cienc 2010;82:2.

11. Sreelakshmi R, Shan P Mohammed, Jyoti Harindran, Sriganesan P. Evaluation of diuretic activity of Mussaenda frondosa. Asian J Pharm Clin Res 2015;8:117-8.

12. Mandeep R Mehra, MD Hector O, Ventura MD. ECG changes in response to diuresis in an ambulatory patient with congestive heart failure. CHF 2006;12:277-83.

13. Task Force of The European Society of Cardiology and The North American Society of Pacing and Electrophysiology. Heart rate variability-Standards of measurement, physiological interpretation, and clinical use. Circulation 1996;93:1043-65.

14. Mohandas Rai, Chandrashekar R, Manohar Vr, Ramya Kateel. Potent and Efficacious diuretic activity with the potassiumsparing effect of Terminalia belerica fruit pulp aqueous extract in Wistar albino rats. Asian J Pharm Clin Res 2016;9 Suppl 1:241-3.

15. James Nolan, MD Phillip D, Batin MD, Richard Andrews, MRCP, et al. Prospective study of heart rate variability and mortality in chronic heart failure-Results of the united kingdom heart failure evaluation and assessment of risk trial (UK-Heart). Circulation 1998;98:1510-6.

16. Leonetti G, Cuspidi C, Facchini M, Stramba-Badiale M. Is systolic pressure a better target for antihypertensive treatment than diastolic pressure? J Hypertens Suppl 2000;18:S13-S20.

17. Charalambos Vlachopoulos, Konstantinos Aznaouridis, Christodoulos Stefanadis. Prediction of cardiovascular events and all-cause mortality with arterial stiffness. J Am Coll Cardiol 2010;55:1318-27.

\section{How to cite this article}

- Patonah Hasimun, Hasballah Zakaria, Elis Susilawati, Jeany Dwiyulia Wardiono. Antihypertensive activity ethanolic extract of bulb Eleutherine americana merr on fructose-induced hypertension rats. Int J Pharm Pharm Sci 2017;9(8):25-28. 